\title{
Nogle tanker om forskning $i$ eller evaluering af socialt arbejdes metoder
}

\author{
JENS GULDAGER \\ I forskning og evalueringer af socialt arbejdes praksis indgår \\ begrebet socialt arbejdes metoder ofte som et centralt analy- \\ sefelt. Samtidig synes det at voere tilfoeldet, at der på et \\ begrebsligt, overordnet plan savnes bidrag til analyse af soci- \\ alt arbejdes metoder. Med udgangspunkt i Sune Sunessons \\ definition afbegrebet socialt arbejdes metoder forsøges det $i$ \\ artiklen at give et foreløbigt bud på, hvilke analyseelementer- \\ eller dimensioner, der kunne vaere frugtbare og relevante ved \\ forskning iog evaluering af det sociale arbejdes metoder.
}

\section{Indledning}

På Center for Forskning i Socialt Arbejde ${ }^{1}$, hvor vi arbejder med forskning i og evaluering af det sociale arbejdes praksis, er det i vores nu snart 5-årige levetid blevet tydeligere og tydeligere for os at vi, såvel som mange andre i feltet, ofte er meget uklare og uafklarede i vores definitioner og anvendelser af begrebet socialt arbejdes metoder.

Det er i sig selv forskningsmæssigt utilfredsstillende at arbejde med uklare eller

Jens Guldager er lektor ved Den sociale Højskole i København, tilknyttet Center for Forskning i Socialt Arbejde og Den sociale Kandidatuddannelse, Ålborg Universitet. inkonsistente begreber og peger på nødvendigheden af en begrebspræcisering i forhold til vores egne undersøgelser. ${ }^{2}$

På den baggrund er det denne artikels formål at bidrage med et indlæg i denne begrebsdiskussion samt give et foreløbigt bud på en begrebspræcisering, der måske

1 Center for Forskning i Socialt Arbejde er et lille forsknings- evalueringsinstitut tilknyttet de danske social højskoler og støttet i en 5-årig forsøgsperiode (der udløber år 2000 ) af Socialministeriet.

2 Det er iøvrigt også min opfattelse, at begrebet socialt arbejdes metoder også i det sociale arbejdes praksis bliver opfattet på mange forskellige og ofte uklare og uafklarede måder.

Guldager:Nogle tanker om forskning i eller evaluering af socialt arbejdes metoder 
kan være frugtbar i forhold til at evaluere og forske i socialt arbejdes metoder.

Det er en begrebsdiskussion på et relativt højt abstraktionsniveau og ikke et forsøg på at belyse, hvorledes det sociale arbejdes metoder empirisk folder sig ud i det sociale arbejdes praksis.

Mængden af evalueringer er i Nordamerika og i vores del af verden steget kraftigt gennem de seneste $30 a^{3}{ }^{3}$ og det gælder også inden for det sociale område. Det falder uden for denne artikels rammer at belyse denne udvikling og baggrunde for den, men der er næppe tvivl om at det blandt andet hænger sammen med øget interesse for kvalitetssikring og kvalitetsstyring inden for det sociale område, hvilket igen må ses $\mathrm{i}$ sammenhæng med dels områdets politiske og økonomiske styring, men også med usikre kundskaber om hvorledes indsatserne på det sociale område fungerer. I forhold til det sidste er man i skandinavisk sammenhæng længst fremme i Sverige med regeringens initiativ sidste år til et program til støtte af kundskabsudviklingen inden for socialtjenesten. ${ }^{4} \mathrm{Og}$ i denne forbindelse udgør evalueringsforskning og evalueringer af det

3 SePeterDahler-Larsen(1998), derbeskriverdenne udvikling og giver bud på baggrunde for den.

4 Generaldirektør og overdirektør i den svenske socialstyrelse, Kerstin WigzellogLarsPettersson (1999) skiver herom: "Syftet sägs i uppdraget vara att skapa en struktur för systematisk kunskapsuppbyggnad och effektiv informationsspridning så att socialtjänsstens insatser $\mathrm{i}$ större utsträckning kan baseres på vetenskap och beprövad erfarenhet." I Danmark er der en tilsvarende, om end langt svagere, oprustning i forhold til at styrke kundskabsgrundlaget for det sociale arbejde, se Socialministeriets rapport (1998) herom. sociale arbejde en af kilderne til at få bedre kundskaber om indsatserne på det sociale område.

Udgangspunktet for evalueringsforskning og for evalueringer af socialt arbejde er meget ofte, at der arbejdes med en overordnet evalueringsmodel, hvori der med forskellig vægt indgår tre hovedelementer:

1 En beskrivelse af udgangssituationen: Det sociale problem eller den sociale problematik, persongruppen, målene for indsatsen mv.

2. En beskrivelse af indsatsen og forløbet: de anvendte midler, tiltag, arbejdsmetoder, arbejdsprocesser mv.

3. En beskrivelse af afslutningssituationen i forhold til udgangssituationen: forandringer, resultater, målopfyldelse, bieffekter mv.

Den overordnede bestræbelse består derefter $i$ at belyse sammenhængen mellem de tre punkter ved at sandsynliggøre, hvordan den givne indsats og processerne i forløbet har bidraget til (eller ikke bidraget til) de forandringer, der måtte være indtruffet - og/eller hvilke andre forhold der har spillet med (samfundsmæssige- organisatoriske- individuelle forhold mv.).

\section{Mål-Middelrationaliteten}

Bag denne overordnede evalueringsmodel ligger der-eller kan der ligge-en mere eller mindre linieær mål-middelrationel tankegang. En rationalitet der kortfattet siger: Med udgangspunkt i de givne problemer defineres målene med indsatsen, derefter vælges de midler, der med sandsynlighed kan opfylde de givne mål, hvorefter ind- 
trufne forandringer, resultater og bivirkninger registreres.

Der er grund til at problematisere den lineære mål-middel rationalitet i forhold til socialt arbejde og det af flere grunde:

1 De forhåndenværende mål kan i større eller mindre udstrækning være bestemt af hvilkejuridiske, institutionelle og organisatoriske rammer og midler der foreligger. Det kan være ud fra de givne lovgivningsrammer, den givne organisations struktur og kultur, de givne institutionspladser, de givne foranstaltningstyper, den givne behandlingsideologi mv.

Man kan - lidt polemisk - sige, at i socialt arbejde kan det være de forhåndenværende midler, der bestemmer hvilke mål der arbejdes med, fremfor de mål der måtte vokse ud af den givne sociale problematik.

I det organisatoriske perspektiv er det et klassisk synspunkt, at mål-middelrationalet er en grundlæggende og dominerende tankeform i den bureaukratiske organisation (Weber 1994), som meget ofte er den organisatoriske ramme for det sociale arbejde.

2 I socialt arbejde er det ofte tilfældet, at der ikke er enighed om målene. Det være sig mellem klient og professionel, mellem professionel og organisation/system eller mellem professionelle indbyrdes. Det betyder at midlerne ikke kan vælges på et sagligt, rationelt grundlag; men vælges udfra et magt, interesse- eller politisk og værdibaseret grundlag.

I nyere tid er denne problemstilling måske skarpest formuleret af Zygmunt Bauman (1995) i hans tese om, at en bureaukratisk organisationsform og en udviklet teknisk mål-middelrationalitet, der var blind for politiske og moralske problemstillinger, var nødvendige forudsætninger for holocaust.

3 Målene med det sociale arbejde kan ofte ikke fastlægges på et håndterligt operativt niveau i udgangssituationen; men fastsættes - og ændres - løbende i arbejds/ påvirkningsprocessen. Det betyder at målmiddel sammenhængen ikke kan være lineær; men i højere grad må beskrives som et dialektisk forløb.

I et bredere perspektiv kan man tillige anføre at sociale problemer ofte har en så sammensat og kompleks karakter, at analysen af dem bliver amputeret $i$ en mål-middelrationalitet, hvor problemer og arbejdsopgaver bliver defineret i netop afgrænsede og adskilte kategorier og begreber således, at deres sammensathed og indbyrdes sammenhæng kan gå tabt.

Det er udfra en lignende tankegang, at nogle forskere definerer bestemte sociale problemer som vilde problemer til forskel for tamme problemer, hvor de tamme problemer karakteriseres ved, at de relativt nemt lader sig definere; mens vilde problemer er svært definerbare og vanskeligt lader sig adskille fra andre problemer, hvorfor deres løsning også vanskeligt lader sig definere, ligesom der ikke er klare kriterier for deres optimale løsning (Krogstrup 1997).

4 Målenei det sociale arbejdekan indholdsmæssigt være grundlæggende forskellige eller indbyrdes modstridende. Stefan Morén (1996) skelner således mellem to typer mål for eller typer på socialt arbejde, som han henholdsvis kalder til-

Guldager:Nogle tanker om forskning i eller evaluering af socialt arbejdes metoder 
pasning og omgestaltning. Han skriver: "Ibland handlar det om en anpassning mellem livssituation och yttre sociala villkor - anpassande eller kompensatoriska insatser - och det är en mycket legitim uppgift. Ekonomiskt bistånd, rådgivning eller andra insatser av servicekaraktär är begränsade i tid och det ställs inga speciella krav på den biståndssökande i form av ändrad livsföring eller ändrade överlevnadsstrategier. När det gäller denne typ av bistånd är det viktigt att kriterierna är entydiga och att alla behandlas lika.

Socialarbetare kan ocksåstå inför uppgiften att medverka till en omgestaltning av den biståndssökandes livssituation. En kaotisk yttre verklighet går hand $\mathrm{i}$ hand med en lika kaotisk inre verklighet och socialarbetaren kan inte medverka till en positiv förändring gennem några enkla insatser eller beslut.

Biståndsinsatsen innebär att socialarbetaren ska medverka till en långsiktig och ofta smärtsam omgestaltning av en svår livssituation, den biståndssökande människan avkrävs förandrad självbild och förändrad omvärldsuppfattning, ändrade överlevnadsstrattegier..... Här finns inga bestämda kriterier och man kan faktiskt säga att alla behandlas olika, måste behandlas olika. När det gäller sådana inslag av mänsklikt bistånd framstår den personliga relationen som ett grundläggande förändringsvillkor. ${ }^{5}$

5 Stefan Morén skriver om socialt arbejde og tilpasningsindsats og gestaltningsindsats: "Anpassning och omgestaltning är biståndsinsatser av helt olika slag, och jag tror att det är ett av
Et eksempel på denne type bistand er den såkaldte psykosociale samtale. ${ }^{6}$

I forhold til forskning i eller evaluering af socialt arbejdebetyder ovenstående indvendinger, at det meget ofte vil være helt skævt at anlægge en lineær mål-middelrationeltankefigur på sammenhængen mellem 1 : mål-2: midler: indsatser og anvendte metoder - og 3: resultater. At rationaliteten eller de fornuftsmæssige tankefigurer bør være dialektiske og processuelle fremfor mekaniske og lineære. Undtagelsesvis skal det, som Morén også fremhæver, anføres at der er typer af tilpasningsarbejde, hvor en lineær mål-middelrationalitet er helt på sin plads som f.eks. tildeling af økonomiske ydelser, forskellige serviceopgaver mv.

\section{Socialt arbejde og metoder $\mathrm{i}$ socialt arbejde}

Sprogligt betyder metode planmæssig fremgangsmåde. Metodik betegner læren om hensigtsmæssige fremgangsmåder.Hvadder er hensigtsmæssigt eller hvilke metoder der er relevante kan alene angives ved at tage udgangspunkt i problemernes eller arbejdsopgavernes karakter. Det indebærer logisk set at begrebet socialt arbejdes metoder fordrer en præcisering af begrebet socialt arbejde. Det fører for vidt her - først og

socialvårdens huvudproblem att man inte har förstått den värld av skillnad som ligger mellan dessa typer av bistånd.....Det specifika med socialt arbete är emellertid att man befinner sig $i$ gränslandet mellan anpassning ochomgestaltning och att man måste behärska detta gränsland.»

6 Se Börjeson (1975), Hessle (1995) og Guldager (2000) 
fremmest fordi det i sig selv er en meget stor opgave - at få et rimeligt analy tisk såvel som empirisk overblik over socialt arbejde som genstandsfelt. Åke Bergmark har forsøgt at danne sig dette overblik (Bergmark 1998). Han skriver i denne forbindelse: " Definitionerna (af socialt arbejde) bygger aldrig på någen form av redovisade systematiska iakttagelser av vad som faktiskt sker på området, vilka operativa mål som reellt är av betydelse eller vilka kännetecken som målgrupperna uppvisar i det verkliga livet. Istället formas en syntes av grova generaliseringar avseende "hur det är" och höjst subjektiva, tillika tids- och kulturberoende, idéer om vad som bör gälla.» Trods denne begrebslige og empiriske usikkerhed i forhold til at afgrænse det sociale arbejdes genstandsfelt uddrager Bergmark 5 forskellige dimensioner der ret ofte forekommer i forskellige afgrænsninger eller definitioner af socialt arbejde. Det er beskrivelser af:

1 Vilka som udför uppgifterna och/eller i vilket sammenhang de verkar (Aktörer).

2 Generell samhällelig funktion eller allmänna mål (Övergripande syfte).

3 Direkt avsedda förändringar (Operativa mål).

4 Vilka grupper man riktar sig till (Målgrupper).

5 För området specifika perspektiv, kunskaper eller värderingar (Professionell särart).

I det følgende vil jeg, ligesom Bergmark, koncentrere mig om punkterne 2, 3 og 4 og dvs. forsøge ikke at tabe disse tre dimensioner af syne - og det gælder måske navnlig punkterne 3 og 4 .

Med hensyn til punkt 2: den overordnede hensigt med det sociale arbejde, så lægger den op til en overordnet socialpolitisk diskussion, der måtte redegøre for de bredere rammer for det sociale arbejde, mere end den retter sig mod metoder i socialt arbejde. Det er dog i mine øjne en vigtig pointe, at det sociale arbejdes overordnede hensigt altid indgår i en socialpolitisk diskurs, der igen hviler på et samfundsmæssigt fundament.

Magaretha Järvinen (1998) skriver i denne sammenhæng i forbindelse med behandling af alkoholisme: „ Det afgørende for udbygningen af et resourcestærkt behandlingssystem forekommer således ikke at være konsumtionens størrelse og alkoholskadernes omfang, men spørgsmålet om hvorvidt alkohol er blevet defineret som et samfundsproblem eller ej.». Det er med andre ord den dominerende samfundsmæssige opfattelse af akoholproblemet der er betydningsfuld for behandlingsapparatets størrelse (og organisering), snarere end alkoholskadernes art og omfang.

I forhold til den sociale behandlings politiske bundethed skriver Levin, Sunesson og Swärd (1998) i en diskussion af selve behandlingsbegrebet: "...at behandlingsbegreppet är kontroversiellt; det är ett politiskt begrepp, men betraktas sällan som ett sådant. Den verklighet som begreppet kommer att omfatta blir därför mångfaldig, modsägande och förvirrande. Mångfalden av betydelser, den oklara innebörden i begreppet och dess ideologiska användning gör sammantaget att diskussionen om behandling i socialt arbete blivit förvirrad«. ${ }^{7}$ Men tilbage til metodebegrebet.

??? kan inte läsa korrändringen

7 Levin, Sunesson og Swärd taler ganske vist her ikke om metoder i socialt arbejde; men

Guldager:Nogle tanker om forskning i eller evaluering af socialt arbejdes metoder 
Når det således er meget vanskeligt at belyse det sociale arbejdes metodebegreb med udgangspunkt i et velafgrænset socialt arbejdesbegreb, må man forsøge at gå andre veje. En nærliggende vej er at se på de afgrænsninger/definitioner af begrebet socialt arbejdes metode, der måtte foreligge. Det har Bergmark \& Lundstöm (1998) gjort. Om deres erfaringer med dette skriver de: „Dessutom kunde vi konstatera att det i stort sett helt saknas svensk litteratur som på ett övergripande plan presenterar och analyserar metoder för socialt arbete. " De tilføjer at det også er tilfældet uden for Sveriges grænser, hvor de henviser til England og USA.

I Danmark har der i mine øjne hersket en vis konsensus om et overordnet metodebegreb - i hvert fald på socialrådgiveruddannelserne på grundbogsniveau, hvor de mest anvendte grundbøger (Hillgaard \& Kaeiser 1979 samt Egelund \& Hillgaard 1993) arbejder med begrebet socialrådgiverfagets fælleselementer. Egelund og Hillgaard skriver: "Vi fastholder, at metoden i socialt arbejde er de fælles metodiske principper: etik, helhedssyn, kontakt og kommunikation samt systematisk tænkning og handling». Uden i

om behandlingsbegrebet i socialt arbejde. Det berører ikke i mine øjne pointen, at den sociale behandling og de metoder der anvendes i denne, såvel som andre indsatser og metoder i socialt arbejde altid indgår i en socialpolitisk kontekst. Det centrale i behandlingsbegrebet i forhold til socialt arbejdes metoder er understregningen af den direkte interaktion og betydningen af relationen mellem klient og behandler. Det er også i denne betydning at f.eks Börjeson $(77,98)$ understreger vigtigheden af relationen mellem klient og behandler i socialt behandlingsarbejde, ligesom Morén (96) gør det. øvrigt at uddybe dette forekommer det mig uklart hvilken analytisk status det ovennævnte metodebegreb har: metoden identificeres som de fælles metodiske principper og i hvilken betydning er etik, helhedssyn, kontakt og kommunikation samt systematisk tænkning og handling metodeprincipper? $^{7}$

Disse uklarheder er så meget desto mere bemærkelsesværdige, da det i udenlandske såvel som danske lærerbøger i socialt arbejdes metoder ofte fremhæves, at et af socialrådgiverfagets centrale kendetegn netop er faget metoder - som altså udfra ovenstående sjældent er begrebsligt klart præsenteret!

\section{Begrebet socialt arbejdes metoder}

Med det her refererede udgangspunkt må bestræbelsen på at afgrænse eller definere socialt arbejdes metoder forsøges på anden vis. Det følgende vil være et forsøg på det ved at tage udgangspunkt $i$ to definitioner af socialt arbejdes metoder. Det drejer sig om bidrag fra Bergmark \& Lundström (1998) og Sunesson (1981).

Bergmark \& Lundström anfører at deres metodedefinition udgår fra internationalt etablerede definitioner som lægger hovedvægten på systematik, hensigtsmæssighed

8 Se diskussion om dette i Socialt Arbejde Skriftserie, nr. 1, 1997, Den sociale Højskole, København: Om undervisning og fælleselementer i socialt arbejde, hvor Tine Egelund skriver om: undervisning i socialt arbejde tanker til inspiration og diskussion, og Marianne Skytte om: Fælleselementerne - støtte eller bremse? 
(ändamålsenlighet) og planlægning. Deres definition lyder: "Metoder får således beteckna sådana strategiskt utformade, planmässiga och systematiska aktiviteter som används i klientarbetet eller för att reglera klientarbetet..« De anfører selv at deres definition af socialt arbejdes metoder er foreløbig og bred, så jeg vil lade den ligge her - og så $i$ øvrigt vente med spænding på deres videre arbejde med den.

Sune Sunesson (1981) har en anden definition på metoder i socialt arbejde. Han skriver: "Jag skulle vilja definiera metod i socialt arbete som ett medvetet sätt att använda vissa arbetsmedel och åtgärder för klienter eller sociala system som man förstår sig på, eller vars tillstånd man åtminstone tror sig känna, där man har en avsigt med sitt arbete och ett antagande om på vilket sätt ingripandet kommer att förändra tillståndet för de människorna man arbetar med."

Det spændende ved Sunessons definition (som jeg læser den) er, at han i sit metodebegreb knytter den konkrete metodeanvendelse sammen med bestemte opfattelser, forståelser af og kendskab til den sociale problematik - og med bestemte hensigter med arbejdet - og med hvad man kunne kalde bestemte forandringstanker.

Udfra ovennævnte definition kan man i forhold til evaluering og forskning i det sociale arbejdes metoder udlede 4 hoveddimensioner:

1 Problemforståelse eller problemopfattelse i forhold til det pågældende sociale problem eller sociale system.

2 Overordnede såvel som mere operative hensigter og mål med anvendelsen af de givne metoder.
3 Overordnede såvel som mere operative forandringstanker og pædagogiske retningslinier.

4 Konkret anvendte midler og fremgangsmåder: indsatser, aktiviteter, foranstaltninger, tiltag, procedurer, arbejdsmodeller, arbejdsformer, arbejdsmåder, redskaber og teknikker.

\section{Ad.1. Problemopfattelse eller problemforståelse.}

Udgangspunktet for socialt arbejde er mennesker eller grupper med sociale problemer og samfund eller systemer, der vedligeholder eller producerer sociale problemer. Afgrænsningerne eller definitionerne af de sociale problemer er på ingen måde indlysende eller givne. På den anden side er det vel en logisk selvfølgelighed, at en given metodes hensigtsmæssighed må vurderes i forhold til hvorledes anvendelsen af den påvirker en given problematik. Eller med andre ord: Metoder kan ikke være hensigtsmæssige i sig selv; de kan alene være hensigtsmæssige i forhold til, hvorledes anvendelsen af dem indvirker på de sociale problemer. Ud fra dette synspunkt er der bag en given metode, som mere eller mindre eksplicit formuleret præmis, indlejret en bestemt problemopfattelse eller problemforståelse i forhold til det givne menneske, den givne persongruppe, samfundet eller det sociale system.

Problemopfattelse eller problemforståelse hviler på overordnede menneske- og samfundssyn såvel som på mere konkrete opfattelser, forståelser, erfaringer og konkret empirisk viden i forhold til konkrete individer, grupper og sociale systemer. Og

Guldager:Nogle tanker om forskning i eller evaluering af socialt arbejdes metoder 
ud fra disse specificeres den givne problemopfattelse eller problemforståelse i forhold til det pågældende individ, den pågældende gruppe eller det pågældende sociale system.

De mere overordnede menneske- og samfundssyn kan bestå af mere eller mindre bevidste forforståelser, af mere eksplicitte teoretiske referencerammer og viden eller af erfaringsbaserede forståelser, og indenfor disse valg af perspektiv i forhold til den givne problematik. ${ }^{9}$

Hvis man skulle eksemplificere dette $i$ forhold til socialt arbejde med individer, kan man sige, at det overordnede menneske- og samfundssyn danner den forforståelse, som socialarbejderen har for den givne sociale problematik før hun eller han har mødt den konkrete klient. Mens hendes eller hans konkrete opfattelse og viden er det personkendskab i form af opfattelse af og viden om den pågældende klient, dennes livshistorie og sociale situation, som socialarbejderen erhverver sig ved journallæsning mv. og ikke mindst i kontakten med den konkrete klient som et særegent individ med en særegen livshistorie og en særegen livssituation..

I et praksisfelt, som socialt arbejde, er den vekselvirkning, der er mellem teoretisk viden og praksisviden, og som indgår i den givne problemopfattelse, vigtig at have øje for. Denne vekselvirkning vil jeg senere i artiklen vende tilbage til.

9 Se Eliasson (1995) og Hessle (1995)

\section{Ad. 2. Hensigter og mål med det sociale arbejde.}

Socialt arbejdes metoder udgår, logisk set, tillige fra mere eller mindre eksplicit formuleredehensigter-overordnede såvel som mere operative.

Hensigterne hviler på de givne problemopfattelser, problemforståelser samt et socialpolitisk fundament, der igen bygger på en given lovgivning samt dennes udmøntning/fastlæggelse i en given organisation.

Fire typer hensigter og mål er almindeligt forekommende ved valg af metoder ${ }^{10}$ :

1 Undersøgelse, udredning og diagnostisering.

2 Forandring, hjælp, behandling.

3 Disciplinering, kontrol.

4 Forebyggelse.

Det er vel indlysende, at disse fire typer hensigter kan hvile på bestemte teori- og vidensgrundlag; men nok så vigtigt er det $\mathrm{i}$ mine øjne at understrege, at de indeholder stærke normative elementer, der indgår i bestemte socialpolitiske opfattelser. Det er tydeligst ved hensigter, der retter sig mod disciplinering og kontrol; men det gør sig også gældende i forhold til de andre typer hensigter. Denne problematik vender jeg kort tilbage til senere i artiklen.

\section{Ad. 3. Forandringstanker}

Indbygget i eller som præmis for en given metodik er der bestemte forandringstanker eller pædagogiske retningslinier, der

10 Denne typologi er lånt fraBergmark\& Lundström (1998). 
begrunder metodernes forandringspotentiale.

Metoder er midler, der tages i anvendelse i det sociale arbejde med henblik på at forebygge, ændre eller stabilisere en tilstand, og det er vel urimeligt at anvende bestemte metoder, hvis man ikke har en begrundet tro på, at de potentielt kan forebygge, ændre eller stabilisere tilstanden. Forandringstanker er den mere eller mindre begrundede tro på hvem, hvad og hvordan den givne tilstand kan forandres eller stabiliseres.

Midler har - eller har ikke - forandringspotentialer eller stabiliseringspotentialer i sig. Har de ikke det, er det ikke rimeligt at benævne dem som midler til forandring eller stabilisering. Har de forandrings eller stabiliseringspotentialer isig, siger logikken vel, at resultatet af anvendelsen af metoderne afhænger af disse potentialer. Analytisk er disse forandrings- eller stabiliseringspotentialer derfor nødvendige for at belyse hvordan og hvorfor en metode virker, som den gør. Forandrings- eller stabiliseringspotentialer kan, hvis de skal oversættes til bevidsthedskategorier kaldes forandringstanker og pædagogiske retningslinier. Denne formulering forsøger at belyse det forhold, at selvom forandrings- eller stabiliseringspotentialer logisk set er nødvendige for at metoder kan virke, behøver den der anvender metoderne ikke at være bevidst om dette eller om dem. Metoderne kan virke uden aktørens bevidsthed herom. Men de kan ikke virke, hvis ikke de indeholder forandrings- eller stabiliseringspotentialer.

\section{Ad.4. Konkret anvendte midler ogfremgangsmåder.}

De konkret anvendte midler og fremgangsmåder dækker, som nævnt, over forskellige typer indsatser, aktiviteter, foranstaltninger, tiltag, procedurer, arbejdsmodeller, arbejdsformer, arbejdsmåder, redskaber og teknikker.

Adskillelsen mellem midler og fremgangsmåder har alene til hensigt at pege på, at et givet middel kan anvendes på forskellige måder. Tvang som middel i socialt arbejde kan eksempelvis anvendes i forskellige grader og på forskellige måder/ fremgangsmåder.

Min hovedpåstand er at de 3 analysedimensioner:Problemopfattelser, hensigter og forandringstanker er frugtbare (og måske endda nødvendige) ved analyse af den 4.: De konkret anvendte midler i socialt arbejde (i parentes bemærket kunne det måske også være tilfældet i forhold til andre praksisfag som f.eks. socialpædagogik, andre pædagogiske fag, sygepleje mv.) .

Det tror jeg, fordi konkret valgte og anvendte midler og fremgangsmåder logisk set hviler på de tre andre elementer.

Sprogligt (fra græsk) betyder metoder som nævnt planmæssige eller hensigtsmæssige fremgangsmåder. Ud fra dette er hensigter (der er altid hensigter bag en plan) en nødvendig præmis i analysen af metoder. Igen er der i første omgang tale om en logisk betragtning. I virkelighedens verden kan hensigterne godt være kendetegnet ved deres fravær, de kan være fuldstændigt uoperationelle, de kan være modsætningsfyldte, selvmodsigende osv. - men det er en anden sag. Men vil man analysere en given

Guldager:Nogle tanker om forskning i eller evaluering af socialt arbejdes metoder 
metodes virkning, må det logiske udgangspunkt være at belyse opfyldelsen af de bagvedliggende hensigter suppleret med sidegevinster, bivirkninger mv. Og igen kan det godt være tilfældet at aktørerne ikke er særligt bevidste om hensigterne, selvom de indgår som et logisk set nødvendigt element i metodebegrebet.

En helt grundlæggende metodelogisk betragtning er, at metoder ikke kan være hensigtsmæssige, uhensigtsmæssige, virkningsfulde eller virkningsløse, gode eller dårlige i sig selv. Det kan de kun være i forhold til en given substans, en given problematik eller en given arbejdsopgave. Derfor forekommer det mig også logisk nødvendigt $i$ analysen af metoder at belyse deres genstandsfelt eller operative område. Igen kan aktørerne være mere eller mindre bevidste om denne problematik. Det er denne bevidsthed der søges belyst med begreberne problemforståelse eller problemopfattelse.

Disse begrundelser for "nødvendigheden" af at belyse de 4 analysedimensioner i metodeanalysen er udtryk for et forsøg på at redegøre for en form for metoderationalitet eller metodekonsistens. I denne forbindelse vil jeg gerne understrege to forhold:

1 Der er, som tidligere anført, i mine øjne ikke tale om en lineær rationalitet der siger at hver enkelt hoveddimension skal være logisk klart og entydigt bestemt. Slet ikke - det er tværtimod min opfattelse, at metoders udfald ofte kan forstås i lyset af de modsætninger de indeholder. Og det samme i forhold til forholdet mellem dimensionerne. Detsidste vil blive eksempliceret $i$ artiklens sidste afsnit.
2 Som det er fremhævet flere gange, er der ikke nogen nødvendig sammenhæng mellem metoderationalitet, metodebevidsthed og metodernes resultater i og med at der kan anvendes konkrete metoder i det sociale arbejde med gode resultater uden de tre første dimensioner er bevidst og klart formuleret og sågar også i tilfælde, hvor der er modsigelser eller inkonsistens imellem dem - det kunne i givet fald forklares med, at det er metodepraksisen dvs. de konkret anvendte metoder der er afgørende for udfaldet -og ikke bevidstheden om deres teoretiske premisser eller logiske forudsætninger. Eller sagt lidt poppet: man kan gøre det rigtige - vælge og anvende relevante metoder på et logisk og teoretisk uholdbart grundlag. Men i forhold til analyse og undersøgelse af socialt arbejdes metoder forekommer det mig rimeligt at være metoderationalist i den betydning, at man forsøger at præcisere sin egen metodefornuft så logisk og teoretisk holdbart, som man nu kan - og så kaste sig ud i virkeligheden. Der vil det så vise sig i hvor høj grad det skitserede metodebegreb er frugtbart til at analysere de konkret anvendte midler og fremgangsmåder i socialt arbejde.

\section{Metodebegreb, teoretisk viden og praksisviden}

Som det er fremgået, er det min opfattelse at metodebegrebet analytisk bør kobles tæet til problemopfattelser, hensigter og forandringstanker. Det er i denne sammenhæng nærliggende at stille sig spørgsmålet om denne koblings karakter, når der som her er 
tale om et praksisfag, hvor problemforståelser, hensigter og forandringstanker i vid udstrækning er erfaringsbaserede.

Erfaringer bygger på konkrete sanseindtryk. En erfaren praktiker er i denne betydning erfaren, fordi pågældende har oplevet (og sanset) mange konkrete tilfælde på det foreliggende område. En erfaren hjertekirurg er således erfaren, fordi hun har diagnostiseret og opereret en masse hjerter. Man kan sige at praksisviden er funderet på mange praktiske erfaringer (og i større eller mindre omfang på teoretisk viden). Begreber er-ultrakort-abstraktioner, der uddrager de væsentlige karakteristika ved et givet fænomen. Teoretisk viden er i denne betydning begrebslig viden (der kan have et mere eller mindre solidt empirisk belæg; men altid en formel tankemæssig klarhed - formelt logisk eller dialektisk - og altid på et bestemt abstraktionsniveau).

Udfra Kant kan man - igen ultrakort - sige: Fornuft er begreber der hviler på erfaringer (hvordan de så gør dette, er der mange varianter og diskussioner af - her kommer videnskabsteoretikerne brasende). Erfaringer uden begreber giver ikke fornuft - begreber uden erfaringer heller ikke. Der er i denne tankegang altid en dialektik mellem erfaringer og begreber. Så ud fra dette - ret banale standpunkt - skal dialektikken i forhold til praksisviden vel først og fremmest styrkes ved at forsøge at begrebsliggøre erfaringerne; mens det i forhold til den teoretiske viden i højere grad gælder om at problematisere erfaringsgrundlaget (udover den begrebslogiske konsistens).

Et eksempel på dialektikken mellem praksisviden og teoretisk viden:

Det er min opfattelse, at vi har rimelig sikker teoretisk viden om, hvad separation mellem børn og forældre betyder for børnene (ved fjernelse fra hjemmet) - og hvad man (praktikeren) derfor skal være opmærksom på og arbejde med. Kort fortalt var udgangspunktet før denne nyere teoretiske viden en dominerende psykologisk opfattelse (Anna Freud m.fl.) der udsagde noget i retning af, at børn fra meget alvorligt belastede familieforhold havde fået ødelagt deres primærrelationer (først og fremmest til deres forældre), og at det var faretruende i forhold til deres evne til senere i livet til at indgå i nære medmenneskelige relationer. Hvis det derfor var tilfældet skulle de fjernes fra hjemmet og forbindelsen til deres biologiske forældre skulle minimeres og alle kræfter sættes ind på at give dem mulighed for (uden de biologiske forældres forstyrrelser) at opbygge nye tætte relationer til deres plejeforældre. Helt bogstaveligt betød det, at man f.eks. i Sverige i nogle tilfælde gjorde det til lidt af en dyd at fjerne børnene over store geografiske afstande, så de biologiske forældre rent praktiskt havde svært ved at kontakte deres børn, og omvendt. Denne teoretiske opfattelse byggede på et psykoanalytisk grundlag og på kliniske erfaringer. Den havde mig bekendt ikke noget empirisk- undersøgelsesmæssigt fundament. »Teorien« blev trængt $i$ baggrunden og erstattet af en anden dominerende opfattelse af tre hovedårsager ${ }^{11}$ : 1 Praktiske erfaringer fra anbringelserne:

11 Det følgende bygger i hovedsagen på Bogen: Bengt Börjeson \& Hans Håkanson: Hotade, försummade, övergivna. Stockholm 1990 samt et foredrag som Bengt Börjeson holdt på Den sociale Højskole i København i 1994.

Guldager:Nogle tanker om forskning i eller evaluering af socialt arbejdes metoder 
ungerne ville meget ofte hjem til deres "umulige" biologiske forældre. De udtrykte stor sorg over adskillelsen. Af samme grunde afviste de ofte deres nye plejeforældre. En del stak af og forsøgte at komme hjem (der er eksempler fra Sverige, hvor børn begav sig alene på rejse helt fra Norrland til Skåne for at komme hjem).

2 En rækkenye undersøgelser først og fremmest fra Sverige og USA der tydede på, at børn generelt tilsyneladende ikke havde gavn af plejeanbringelserne set i forhold til deres psykologiske og sociale udvikling - de børn der havde gavn af det, var børn der havde kontinuert kontakt med deres (stadigt umulige) biologiske forældre.

3 En ny psykologisk orientering (i et såkaldt relationsteoretisk perspektiv) der kortfattet udsagde, at børn der bliver adskilt fra deres forældre oplever et traumatisk tab, en grundlæggende frygt for at være blevet afvist og derfor en alvorlig sorg. At adskillelsen, tabet, svigtet og sorgen for barnet udgjorde et så alvorligt indre psykologisk drama at det, hvis dette drama blev undertrykt(eller overset) kunne give anledning til alvorlige psykologiske traumer og dermed være blokerende eller forstyrrende for barnet psykologiske og sociale udvikling, herunder også dets evne til at knytte nære medmenneskelige relationer.

Denne foreløbigt sejrende teoretiske opfattelse forekommer mig at være rimeligt underbygget teoretisk såvel som empirisk. Hvis det er sandt, er den en meget vigtig generel viden for praktikeren. Hun/ han ved, at hun/han ikke - som man gjorde det tidligere - må afskære og udelukke de biologiske forældre, at kontinuiteten bør bevares og at der skal arbejdes med barnets adskillelsessorg, -tab, -traume. (I parentes bemærket ligger der i dette ikke argumenter for ikke at fjernes børn; men alene argumenter for hvad adskillelsen betyder og hvad man skal være opmærksom på i denne forbindelse.) I denne betydning er den teoretiske viden meget værdifuld for praktikeren som retningsgivende for hvordan hun/ han skal opfatte fænomenet (adskillelsen) og hvad hun/han skal være opmærksom på i denne forbindelse - samtidig med at den er helt utilstrækkelig for praktikeren i forhold til hvad og hvordan hun/han skal handle i forhold til et konkret barn i en konkret plejefamilie og med konkrete biologiske forældre. Det tror jeg i hovedsagen skyldes to forhold:

1 At teoretisk viden er abstrakt viden der kun kan være retningsgivende på sit eget abstraktionsniveau - de utallige mulige konkrete former for adskillelsestraumer kan den teoretiske viden ikke sige noget om; den kan alene sige, at hvis der tale om et adskillelsestraume bør det bearbejdes og en eller anden form for kontakt med de biologiske forældre bevares. Da den teoretiske viden ikke kan sige noget om de mulige konkrete former for adskillelsestraumer (den kan højst sige noget om nogle mere eller mindre udbredte hovedtyper) kan den selvsagt heller ikke give relevante konkrete operative anvisninger i forhold til en ukendt konkret form.

2 At den konkrete situation eller virkelighed er så sammensat og mangfoldig og dermed så kompliceret, at den i sin helhed ikke kan fattes. Ja - undskyld mig banali- 
teten; men jeg tror faktisk også det er en pointe. Jean-Paul Sartre (1969) udtrykker det således: »Konsekvenserne af vores handlinger ender altid med at glide os af hænde, fordi ethvert tilrettelagt forehavende, såsnart det er virkeliggjort, træder i forbindelse med hele universet, og fordi denne uendelige mangfoldighed af forbindelser overstiger vores fatteevne.» Dette svarer til den danske filosof Peter Zinkernagels opfattelse af, at der er " uoverskuelig mange måder en konkret situation kan beskrives på." Og at "enhver (sådan) konkret situation er komplet uoverskuelig." (Zinkernagel 1992, se også Israel 1983).

Praktikerens opfattelse af det konkrete barn, de konkrete biologiske forældre, de konkrete plejeforældre (deres personer, deres samspil, deres sociale forhold osv.) indeholder så mange facetter (variable) at det ikke lader sig gøre at opfatte dem alle og slet ikke deres komplicerede sammenspil - og i denne betydning kan praktikeren principielt ikke have sikker eller fuldstændigt dækkende viden i den konkrete situation. $^{12}$

Det første punkt er vel en logisk selvfølgelighed; mens det andet punkt måske er vigtigt i forhold til hvad erfaringer er. Den meget erfarne praktiker er måske kendetegnet ved at hun/han har prøvet at vurdere og handle i mange børnefjernelsessager og

12 Ingrid Claezon udtrykker en ligende skepsis overfor socialarbejderens mulighed for at have et sikkert vidensgrundlag i det praktiske arbejde, uanset om det drejer sig om et solidt erfaringsgrundlag eller det teoretiske vidensgrundlag (her taget fra Marianne Skyttes omtale af Ingrid Claezons afhandling: Bättre beslut. Umeå 1987, se note 8). derfor qua sine erfaringer har dokumentation for det unikke og kompleksiteten i hver enkel sag. Erfaringer i denne betydning er ikke nødvendigvis nogen kvalitet i sig selv. Den udygtige erfarne socialrådgiver tager ingen konsekvenser af sine mange erfaringer; men vurderer og handler hovedkulds hver gang. Den dygtige erfarne praktiker forsøger at sætte sine erfaringer på begreb - uddrage mere generelle konsekvenser af dem;man kunne ogsåsige at hun/han opbygger sin personlige teoretiske viden - ligesom hun/han holder sig orienteret om den teoretiske viden indenfor sit arbejdsfelt - men stadig med øje for abstraktionens begrænsninger i forhold til at håndtere en konkret situation og dvs. med respekt og usikkerhed i forhold til det unikke og kompleksiteten i hver konkret situation. Og endelig tror jeg, at den dygtige praktiker er kendetegnet ved at hun/han på baggrund af sine mange erfaringer har udviklet intuitive ${ }^{13}$ evner. - Det er med nogen betænkelighed at jeg bruger begrebet intuition - mest fordi det kan være

13 Intuitionsbegrebet har i samfundsvidenskaben såvel som i forhold til socialt og pædagogisk arbejde fået en vis gennemslagskraft i Danmark ved introduktion af Hubert \& Stuart Dreyfus's læringsmodel(Flyvbjerg 1991). Det forekommer mig dog at selve begrebet og den næunte læringsmodel er særdeles uigennemsigtig. Ligesom jeg synes, at der i dette intuitionsbegreb ligger en mekanisk og fejlagtig tankegang, nemlig at mange erfaringer fører til intuitiv forståelse eller ekspertice, hvor eksperten ifølge Flyvbjerg er karakteriseret ved: Intuition, holistisk og synkron identifikation af problem, mål, plan, beslutning og handling. Flydende, utvungen, præstation, som ikke afbrydes af analytiske overvejelser. Dialektikken mellem analytiske overvejelser og intuition er i mine øjne her

Guldager:Nogle tanker om forskning i eller evaluering af socialt arbejdes metoder 
islægt med eller have forbindelse til okkultemystiske opfattelser - og det er ikke lige min boldgade. Fysikeren Benny Lautrup ${ }^{14}$ definerer intuition således: wintuition er vel heller ikke mystisk, men kunne "blot» være evnen til at integrere et stort antal svage signaler i et støjfyldt miljø. » Og det er jf. ovenstående lige netop det den dygtige praktiker skal kunne samtidig med at hun/han anvender sin personlig teoretiske viden (uddraget af egne erfaringer) og den relevante foreliggende teoretiske viden.

Hvis ovenstående dilemmaer - og usikkerheder - er gældende for praksisfeltet, har det den implikation, at de også påvirker metodebegrebet på den måde, at de spiller ind i forhold til de problemopfattelser, hensigter og forandringstanker, der ligger til grund for de konkret anvendte midler og fremgangsmåder. Det må derfor give anledning til en vis forsigtighed blandt os, evaluatorer af det sociale arbejde, når vi kommer anstigende med vores krav om metoderationalitet og metodekonsistens.

\section{Metoderationalitet, metodekonsistens, problemforståelse og etik}

Som det er fremgået forsøges det i nærværende artikel at forfægte en metodera-

erstattet med (den noget uklare) intuition. Intuitionsbegrebet forekommer tillige ensidigt positivt formuleret, som om mange erfaringer i sigselv giverkvalitative intuitivekundskaber.Det behøver bestemt ikke at være tilfældet. Se en udmærket kritik af Drefussernes læringsmodel og intuitionsbegreb i Dirckinck-Holmfeld \& Remmen (1999).

14 Herciteret fra en artikel i Dagbladet Information d. 4/6-1997. tionalitet ved at foreslå nogle analytiske elementer eller dimensioner (problemforståelse, hensigter/mål, forandringstanker og konkret anvendte midler og fremgangsmåder), det måtte være frugtbart at arbejde med ved forskning i eller evaluering af socialt arbejdes metoder. Der argumenteres i forlængelse heraf for en metodekonsistens $i$ betydningen, at overensstemmelse mellem disse elementer er udtryk for konsistens, mens uoverensstemmelse eller modsætninger mellem dem er udtryk for en inkonsistens eller en arbitrær metodeanvendelse. Som det er nævnt skal konsistens ikke forstås som en logisk liniær forbindelse elementerne imellem, men snarere som en dialektisk vekselvirkning, hvor de enkelte elementer påvirker og er afhængige af de andre. I dette samspil består konsistens i elementernes indbyrdes og gensidige overensstemmelse, mens inkonsistens karakteriseres ved deres indbyrdes uoverensstemmelse eller modsætningsfyldthed. Eksempelvis uoverenssstemmelse/modsætning mellem problemopfattelse og hensigt, mellem hensigt og forandringstanker, eller mellem disse og de konkret valgte midler og fremgangsmåder.

I forhold til denne opfattelse af metoderationalitet og metodekonsistens er det vigtigt at fremhæve to meget centrale forbehold:

1 Metodekonsistens er ikke i sig selv en tilstrækkelig betingelse for at indsatsen bliver relevant og at der opnås de ønskede resultater.

2 Metodekonsistens kan, hvis den ikke bygger på et etisk og almenmenneskeligt perspektiv, sammen med magtudøvelse udgøre en farlig cocktail, hvor den pro- 
fessionelle arbejder "korrekt» og konsistent, men hvor konsekvensen er undertrykkelse og umyndiggørelse af klienter.

Begge forbehold kan illustreres ud fra Zygmunt Baumans (1995) analyser af holocost: Meget kortfattet må man vel sige, at nazisternes udryddelse af jøderne var båret af stor metodekonsistens. Deres problemopfattelse, at jøderne udgjorde et alvorligt undergravende element i forhold til det tyske samfund, samt at jøderne racemæssigt var arierne underlegne hænger sammen med hensigten med at uskadeliggøre dem og senere likvidere dem. Ligesom deres forandringstanker/forandringsstrategi om først at vende offentligheden mod dem, senere tage deres borgerlige rettigheder fra dem, for så at isolere dem og i sidste ende udrydde dem, fungerede i overensstemmelse hermed, ligesom de konkret anvendte midler og fremgangsmåder i forløbet gjorde det (det sidste kan eksempelvis illustreres ved skiftet fra at skyde jøder, senere gasse dem i lastbiler for endeligt at gasse dem i udryddelseslejre). Dette grusomme og ekstreme eksempel belyser vel den farlige cocktail mellem magtudøvelse og metodekonsistens. En farlighed der analytisk vel først og fremmest hænger sammen med to hovedforhold.

For det første, at metodekonsistens kan hvile på en helt illusorisk problemopfattelse (jøderne udgjorde ikke et alvorligt undergravende element i det tyske samfund, raceteorierne har ikke bund i nogen virkelighed).

Som et mindre dramatisk eksempel på metodekonsistens og utilstrækkelig problemforståelse kan nævnes en evaluering af et familiebehandlingssted(Guldager 1999), hvor man i mine øjne arbejdede ret metodekonsistent, men hvor problemforståelsen hvilede på et snævert systemteoretisk grundlag, der i nogle tilfælde gav en utilstrækkelig forståelse for klienternes problematik. Kritikken af teorigrundlaget retter sig mere generelt mod såkaldte samhandlingsteorier ${ }^{15}$, hvor analysen er på gruppeniveau, individerne og samfundet er stort set kendetegnet ved sit fravær. ${ }^{16}$

For det andet kan hensigter og forandringstanker hvile på et helt uacceptablet etisk og umenneskeligt grundlag. I holokosteksemplet er den etiske dimension åbenbar. I forhold til det præsenterede metodebegreb er der indlejret etiske og politiske dilemmaer i forhold til de værdipræmisser, der ligger til grund for den givne problemopfattelse, ved valget af hensigter og forandringsstrategi og ved valget af de konkrete midler og fremgangsmåder.

Den danske socialretsfilosof Peter Høilund (2000) fremhæver i denne sammenhæng med udgangspunkt i Ricoeur`s diskussion af Gademars opfattelse af fagmetoder, at fagmetoder kan være vejen til "sandheden", hvis de bygger på en praktiseret etik, og en vigtig indgang til en sådan er at have øje for forholdet mellem fagmetode og menneskets (her klienternes) oplevelsesverden.

15 Se f.eks. Nils Mortensen og Gorm Harste: Sociale samhandlingsteorier, i Heine Andersen og Lars Bo Kaspersen (red): Klassisk og moderne samfundsteori. København 1997. Hans Reitzels Forlag

16 Et vigtigt bidrag i denne diskussion om sociologiens analyseniveauer er: Thomas Brante: Kausal realism och sociologi (1997).

Guldager:Nogle tanker om forskning i eller evaluering af socialt arbejdes metoder 


\section{Afrunding}

Som anført $\mathrm{i}$ indledningen har det været denne artikels formål at yde et bidrag til diskussionen om indholdet i begrebet: socialt arbejdes metoder samt give et foreløbigt bud på præcisering af dette begreb i forhold til forskning og evaluering af indsatser på det sociale område.

Overordnet består buddet i en begrebsanalyse, hvor 1: de konkret anvendte midler og fremgangsmåder i det sociale arbejde analyseres i forhold til 2: de problemopfattelser 3: de hensigter og mål og 4. de forandringstanker, der ligger til grund for den konkrete indsats - ud fra den tanke, at manglende konsistens i og manglende overensstemmelse mellem de fire analysedimensioner er udtryk for en svigtende metoderationalitet. Og svigtende metoderationalitet vil i denne sammenhæng sige, at det anvendte metodebegreb forekommer arbitrært, hvilket selvsagt er utilfredsstillende i forhold til det sociale arbejdes praksis, og det er et vigtigt fokus for forskning- og evalueringsvirksomhed på området.

Igen skal det understreges, at den her fremhævede metoderationalitet ikke må forstås som en simpel lineær mål-middelrationalitet, men som en rationalitet, hvor mål og midler analyseres i deres gensidige vekselvirkning eller dialektik i forhold til den givne sociale problematik, de deltagende aktører og det sociale system.

Ligesom det skal pointeres at metoderationalitet eller metodekonsistens i sig selv ikke på nogen måde sikrer relevante indsatser eller resultater på det sociale område, idet relevans og resultat altid hviler på forskellige etiske og politiske positioner.
En vigtigt etisk/politisk diskussion i denne sammenhæng drejer sig om klienters medbestemmelse og medinddragelse ved valg af problemopfattelse, hensigter og forandringsveje; men det fører ud over denne artikels rammer.

Empirisk har vi på Center for Forskning $\mathrm{i}$ Socialt Arbejde forsøgt at analysere forskellige konkrete indsatser ud fra ovenstående metoderationalitet med de fire analysedimensioner.

I den kvalitative del af en undersøgelse af aktiveringen i en københavnsk omegnskommune (Ebsen, Guldager, Hagen 1999) skelnes der mellem 7 forskellige typer arbejdsløse ud fra følgende variable: 1. Køn, alder, livshistorie og livsfase 2. Arbejdsog arbejdsløshedsforhold, herunder varighed og oplevelse ved og under arbejdsløshed, handlemønstre under arbejdsløshed, arbejdserfaringer -og kvalifikationer 3 . Netværk, fritidsinteresser, aktiviteter og hverdagsliv 4. Forhold til socialforvaltningen, herunder erfaringer og holdninger til denne 5. Fremtidsorientering og fremtidstro.

Ud fra disse typologier forekommer det klart, at de forskellige typer har forskellige problemer som aktiverede arbejdsløse samt forskellige resourcer, muligheder og fremtidsperspektiver og det vil sige, at det er uomgængeligt, at der må ligge forskellige problemopfattelser til grund for hver type - og i forlængelse heraf også forskellige hensigter/mål og forandringstanker i forhold til den konkrete indsats. En af vores konklusioner i denne del af undersøgelsen er netop, at den sociale indsats mislykkes eller bliver undertrykkende i de konkrete tilfælde, hvor problemopfattelserne hviler 
på et for tyndt grundlag, samt, hvor der er manglende konsistens i eller overensstemmelse mellem de fire analysedimensioner. I tre andre små evalueringer (Guldager 1998, $1998,1999)$ har jeg forsøgt med de samme 4 metodeelementer at analysere de anvendte metoder i det sociale arbejde.
Generelt synes jeg, at erfaringerne med at forsøge at anvende det refererede metodebegrebikonkrete evalueringer er såfrugtbare, at det er forsøget værd at gå videre ad denne vej.

\section{Litteratur}

Bergmark, Åke (1998). Nyckelbegrepp i socialt arbete. Lund. Studentlitteratur.

Bergmark,Åke\&Lundström, Tommy (1998). „Metoder i socialt arbete" i Socialvetenskaplig tidsskriftnr. 4, 1998.

Bauman,Zygmunt (1995). Modernitet og holokaust. København. Hans Reitzels Forlag.

Brante Thomas (1997). „Kausal realism och Sociologi« i Sociologisk Forskning, nr. 37, 1997.

Börjeson, Bengt (1975). Et spørgsmål om identitetsamtale med K. København. Munksgaard.

Börjeson, Bengt (1977). Behandlingen. Stockholm. Almqvist \& Wiksell.

Börjeson, Bengt (1998). „Om klientsynen på Barnbyn Skåu i Socialmedicinsk tiskrift nr. 7, 1998.

Börjeson, Bengt \& Håkansson, Hans (1990). Hotade, försummade, övergivna - är familjehemsplacering en möjlighet för barnen? Stockholm. Rabén \& Sjögren.

Dahler-Larsen, Peter (1998). Den rituelle reflektion-omevalueringer i organisationer. Odense. Odense Universitetsforlag.

Dirckinck-Holmfeld,Lone\& Remmen, Arne(1999). "Forståelse og forandring i læreprocesser" i Universitetspaedagogik for Adjunkter, del 1. Ålborg Universitet.

Ebsen, Frank \& Guldager, Jens \& Hagen, Ulla (1999). Arbejdsløse og aktivering. København. Samfundslitteratur.

Egelund, Tine\& Hillgaard,Lis(1993). Socialrådgivning og social behandling. København. Munksgaard.

Egelund, Tine (1997). „Undervisning i socialt arbejde - tanker til inspiration og diskussion" i Socialt Arbejde Skriftserie, nr. 1, 1997, Den sociale Højskole, København: Om undervisning og fælleselementer i socialt arbejde,

Eliasson, Rosmari (1995). Forskningsetik och perspektivval. Lund. Studentlitteratur.

Flyvbjerg, Bent (1991). Rationalitet og magt, bind 1. København. Akademisk Forlag.

Guldager, Jens (1998). Sophiehaven - arbejdet $i$ kommunens børne- og ungegruppe. København. Center for forskning i Socialt arbejde.

Guldager, Jens (1998). Hallo! Hvad med i morgen? Evaluering af revaliderings/aktiveringsprojekt på Center for Rådgivning og Udvikling. København. Center for Forskning i Socialt Arbejde.

Guldager, Jens (1999). Evaluering af Poppelgården Familiecenter. Købehavn. Center for Forskning i socialt arbejde.

Guldager, Jens (2000). Noerkontakt med det offentlige- et liv som bistandsklient. København. Hans Reitzels Forlag.

Hillgaard, Lis \& Keiser, Lis (1979). Social (be) handling. København. Munksgaard.

Hessle, Sven (1995). Samtaler med B - om at finde sit sprog. København. Hans Reitzels Forlag.

Høilund, Peter (2000). Socialretsfilosofi. København. Gyldendal.

Israel, Joachim (1983). Kunsten at bloese en ballon op indefra. København. Gyldendal.

Järvinen, Margareta (1998). Det dårlige selskab. København. Forlaget SocPol.

Krogstrup, Hanne Kathrine (1997). Brugerinddragelse og organisatorisk loering i den sociale

Guldager:Nogle tanker om forskning i eller evaluering af socialt arbejdes metoder 
sektor. Ålborg. Systime.

Levin, Claes \& Sunesson Sune \& Swärd, Hans (1998). »Behandling» i Verner Denvall och Tord Jacobson (red.): Vardagsbegrepp i socialt arbete. Stockholm. Norstedts Juridik.

Morén, Stefan (1996). Förändringens gestalt.Om villkoren för mänskligt bistånd. Stockholm. Publica.

Mortensen, Nils \& Harste, Gorm (1997). „Sociale samhandlingsteorier« i Heine Andersen og Lars Bo Kaspersen (red) Klassisk og moderne samfundsteori. København. Hans Reitzels Forlag.

Sartre, Jean-Paul (1969). Eksistentialisme og marxisme. København. Gyldendal.

Skytte, Marianne (1997) „Fælleselementerne - støtte eller bremse?» i Socialt Arbejde Skriftserie, nr. 1, 1997, Den sociale Højskole, København.

Socialministeriet (1998). Rapport fra Socialministeriets udvalg vedr. forskning i socialt arbejde. København.

Sunesson, Sune (1981). När man inte lyckas. Stockholm. Almqvist \& Wiksell Förlag.

Weber, Max (1994). Magt og byreaukrati. København. Det lille Forlag.

Wigzell, Kerstin \& Pettersson, Lars "Socialtjänsten ska baseras på vetenskap och beprövad erfarenhettet", i Socionomen nr. 7, 1999.

Zingernagel, Peter (1993). Virkelighed. København. Munksgaard.

\section{Summary \\ Some thoughts about research into and evaluation of methods in social work}

The article contains a discussion of the concept of methods in social work and of the variables and dimensions which could be fruitful and relevant for research into methods employed in social work and in evaluation of these methods.

The purpose of the article is to contribute to the discussion of what is contained in the concept of methods in social work and to make a tentative proposal for ways of making that concept more precise when used in evaluation of practice or research in the area.

A focus on the problem is deemed necessary because a lack of consistency in dimensions of analysis will automatically result in an unsatisfactory arbitrary outcome, both in the practice of social work and in related research. The author sees doubtful poten- tial for consistency between the dimensions cited in Sune Suneson's definition of methods in social work, where concrete ways and means in practical social work are analysed in relation to: (1) various perceptions of the problem, (2) various intentions and goals, (3) various underlying thoughts of change, upon which the actual intervention employed by the various social workers is based.

The proposed rationality of method must not be understood as a classical simple linear sequence of methods required in order to achieve the goal, but rather as a sort of rationality best summarized as a dialectic. In this dialectic the very interplay between the three dimensions is analysed in relationship to the applied concrete ways and means of social work, and in relation- 
ship to a sufficient specification of all parties involved and the existing social system with its ethical code and political basis.

The author argues furthermore that rationality of method or consistency of methods does not in itself assure relevance or suitable results in the social area, since relevance and results are always based on a sub- stantial analysis of the given social issue, and are viewed from a given ethical and political position.

The author points out some productive results achieved in analysis work, when the three dimensions of analysis were employed in concrete evaluations of applied methods in practical social work.

\section{Dags att förnya prenumerationen på Socialvetenskaplig tidskrift 2001}

Prenumerationspriser per år, SEK

$\begin{array}{lrrr} & \text { Sverige } & \text { Norden } & \text { Övriga länder } \\ \text { Enskild } & 175:- & 210:- & 220:- \\ \text { Institution } & 375:- & 410:- & 420:-\end{array}$

FORSA tillhandahåller tidskriften åt medlemmarna. Enskilda nummer av tidskriften kostar 110:-, dubbelnummer 150:-.

Skicka prenumerationsbeställningen till:

Prolog, Kolonivägen 2, 14144 Huddinge, fax 08-774 13 77, tel 08-779 55 19, e-post: prolog@swipnet.se, Pg 134 35 97-9. Org.nr 556200-3862.

Under 2001 kommer vi att presentera många spännande artiklar och teman. 